\section{En liten og grei håndbok om smertebehandling}

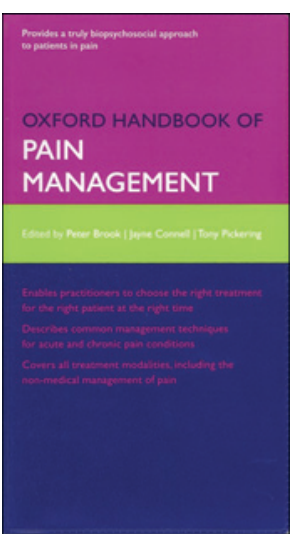

Peter Brook, Jayne Connell,

Tony Pickering, red.

Oxford handbook of pain management

366 s, tab, ill. Oxford: Oxford University Press,

2011. Pris GBP 33

ISBN 978-0-19-929814-3

Dette er en håndbok i smertebehandling på 360 små sider, skrevet av i alt 45 forfattere og tre redaktører. Målgruppen er travle klinikere i primærhelsetjenesten og sykehusleger i spesialisering. Redaktørene vedgår at en slik knapp bok ikke er utfyllende. Men som en «lommebok» for hurtigoppslag er den grei nok.

En typisk lærebokfeil har de ikke klart å unngå: De hevder en gammel sannhet, som nå er motbevist: Buprenorfin er godt dokumentert å ha additiv, til og med «supraadditiv», analgetisk virkning når det gis sammen med morfin eller oksykodon. Hele tre steder står det at buprenorfin har en antagonistisk virkning når det gis sammen med andre opioidanalgetika. Det er feil (1).

Det finnes tilsvarende bøker på markedet som jeg synes har fordeler fremfor denne. Massachusetts General Hospital, med Jane Ballantyne som redaktør av tredje utgave, har utgitt en håndbok som er mer omfattende og betydelig mer solid (2). Et annet utmerket alternativ er den lille studentboken til sir Michael Bond og Karen Simpson (3). Den gir en god innføring i de mange og sammensatte helseproblemene hos pasienter med vanskelige smertetilstander.

\section{Harald Breivik}

Avdeling for smertebehandling

Oslo universitetssykehus, Rikshospitalet

\section{Litteratur}

1. Kress HG. Clinical update on the pharmacology, efficacy and safety of transdermal buprenorphine. Eur J Pain 2009; 13: 219-30.

2. Ballantyne J. red. The Massachusetts General Hospital handbook of pain management. 3. utg. Philadelphia: Lippincott Williams \& Wilkins, 2006.

3. Bond MR, Simpson KH. Pain: its nature and treatment. Edinburgh: Churchill Livingstone Elsevier, 2006

\section{Flott medisinhistorisk bildebok}

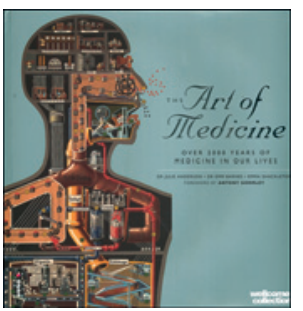

\author{
Julie Anderson, Emm Barnes,
}

Emma Shackleton

The art of medicine

Over 2,000 years of images and imagination.

256 s, ill. East Sussex: Ilex Press, 2011

Pris GBP 30

ISBN 978-1-907579-13-4

Forfatterne, som er anerkjente engelske medisinhistorikere og forskere, har skrevet og dokumentert medisinhistorie ved å analysere verker fra Wellcome-instituttets samlinger.

Burroughs Wellcome \& Co, London, var fra 1880-årene et av verdens ledende medisinfirmaer med forskningslaboratorier og verdensomspennende markedsføring. I dag er selskapet en del av GlaxoSmithKline, mens Wellcome-instituttet gjenstår som medisinhistorisk forskningsinstitutt, med en stor samling av medisinskhistorisk materiale. Instituttet har bøker, malerier, skulpturer, plakater, medisinske instrumenter, apotekutstyr, medikamenter etc. fra hele verden og fra over 2000 år tilbake i tid.

Sir Henry Wellcome (1853-1936), opprinnelig fra USA, var en foregangsmann i medisinproduksjon. Han var også en lidenskapelig samler med god råd, reiste verden rundt og samlet gjenstander av medisinsk interesse. Det sies at enkelte av kassene han sendte hjem til England, ikke ble åpnet før etter hans død. Instituttet har fortsatt med å samle inn gjenstander like opp til vår tid.

Forfatterne beskriver utvalgte gjenstander fra samlingen, med et eller flere bilder per side, og med korte historiske kommentarer ved siden av. Anatomihistorien The Mapping of the Body har, naturlig nok, fått stor plass. Mange gamle praktfulle anatomiatlas er omtalt Beskrivelsene starter med gamle autopsibeskrivelser og anatomiforelesningssaler og ender opp med elektronmikroskopiske bilder.

I tillegg til vestlig medisinhistorie gir forfatterne oss korte glimt inn i andre kulturers medisinhistorie. Vi får beskrivelser av astrologi, homøopati, akupunktur, frenologi - hodeformens betydning og ayurveda, retninger som har vært, og er, anerkjent medisinsk lære i forskjellige kulturer og til forskjellige tider, og som har hatt varierende status innen vestlig medisin.

Livets forskjellige faser, medisin og død og medisin og tro har fătt sine kapitler, likeså sykdomsoppfatning gjennom tidene. Mange forskjellige sykdommer er representert i bilder og skulpturer. Humor i medisinen er ikke uteglemt, og både leger og pasienter får sitt.

De valgte illustrasjonene har åpenbart betydelig kunstnerisk verdi, selv om historikerne ikke har foretatt kunsthistoriske vurderinger. Språket er godt og fagterminologien forståelig for folk flest.

Man kan mene hva man vil om rike engelskmenn som reiste verden rundt, samlet, kjøpte og «fikk» verdifulle historiske gjenstander og tok dem med tilbake til England. De tok i hvert fall vare på historien.

Boken er en praktfull bildebok for oss som gjerne vil vite «litt om mye». Jeg anbefaler den for alle leger, også de som (foreløpig) ikke er interessert i medisinsk historie.

Ingegerd Frøyshov Larsen

Oslo 